\title{
DAIRY CATTLE SHELTER MANAGEMENT SYSTEM FOR STRENGTHENING MILK PRODUCTION
}

(With special reference to World Milk Day-2014)

\section{Champak Bhakat and Tapas K Dutta \\ ERS, NDRI, Kalyani (bhakat@scientist.com)}

The Food and Agriculture Organization (FAO) of the United Nations started the celebration of World Milk Day on June 1, 2001 with a mission to make sure people have regular access to high quality food to lead active and healthy lives. FAO has been working to improve the nutrition, agricultural productivity and lives of rural populations as well as contribute to the growth of the world economy. Calcium in milk is still the easiest way to get the recommended daily allowance. Calcium assists not only to prevent bone loss, but may also reduce the risk of developing high blood pressure and colon cancer (Harvard School of Public Health). Milk also provides other high quality nutrients such as protein, vitamins $A, D, B 12$, riboflavin; zinc; potassium and magnesium.

The dairy cattle require shelter for protection and comfort. The animals are to be protected from high and low temperature, strong thermal radiation, heavy rainfall, high humidity, frost, snowfall, strong winds, ecto-parasite and endo-parasites. Temperature humidity complex causes more stress to animals in India. Rainfall in cold climate also causes stress in temperate zone. Strong winds further aggravate the conditions both in tropics and temperate climate. It is important to provide a sufficient flow of air through the housing/shelter in which the dairy animals are kept to ensure optimum thermal conditions for maximum production.

\section{Type and Systems of Housing for Dairy Animals:}

Two types of housing are in general use at the present time.

1. The loose housing with some type of milking barn.

2. The conventional dairy housing.

\section{Loose housing system:}

Loose housing may be defined as a system where animals are kept loose except milking and at the time of treatment. The system is most economical. Some features of loose housing system are as follows.

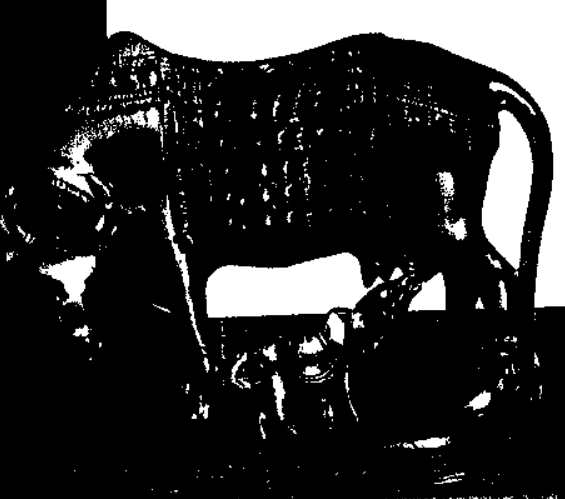

1. Cost of construction is significantly lower than conventional type.

2. It is possible to make further expansion without change.

3. Facilitate easy detection of animal in heat. 
4. Animals feel free and therefore, proves more profitable with even minimum grazing

5. Animals get optimum exercise which is extremely important for better health production.

6. Over all better management can be rendered.

Such system is ideal for areas of low rainfall such as Punjab, Haryana, Rajasthan, Western U.P. and parts of Gujrat, Madhya Pradesh and Maharashtra. Even at other places this system can be used after making small modifications so as to protect animals from excessive rains. In loose housing, animals are usually kept loose in a open paddock in group of 40-50 throughout the day and night except during milking and some other specific purposes like treatment, breeding etc., when the animals are required to be tied. This housing system generally provides continuous manger along with covered standing space, open paddock which is enclosed by brick wall or railing and common water trough. A separate structure of calf pens, milking byres, calving pens, bull pens etc., are required for this system. Thus keeping in view the cost of housing/shelter and the investment required a loose housing system may be desirable. Such houses are more congenial to efficient management, less prone to fire hazards to animals and helps cleaner milk production as a special milking barn/parlour is attached. On the other hand in the conventional closed system there is greater protection during winter season but proportionally the cost is very high.

The loose housing system however, may not be wholly suitable for all agro-climatic zones in India. The climate of India varies from region to region. Housing of the cattle is therefore to be planned and designed as per the agro-climatic conditions prevailing in a particular area. There are some short fall in the loose housing system for replication under different agro ecological regions which can be modified to suit requirement for different regions of the country. .

Heavy rainfall areas: The design of typical loose housing structure for the adult animals would be similar to general loose housing system except additional provision of covered resting area in one side of the paddock which will provide sufficient dry area for the animals during rainfall and provide protection against strong wind. The floor of the resting area should be slightly elevated from open paddock and one side should be closed with brick wall which will work as wind break.

Hot dry areas: The suitable design of loose housing structure for hot dry area could consider covered resting area in the middle of the open paddock with thick tree shade. This would provide indirect shaded area for animals during hot sunny day which saves the animals from direct solar radiation. All the sides of the resting area should be left open to facilitate free air passage (Champak et al, 2006).

Temperate high altitude areas: In temperate area, partially loose housing along with the closed conventional system of housing is desirable. In this system due attention is given to protect animal from heavy snow fall, rain and strong wind. Tail to tail system of conventional barn, completely roofed and enclosed with side wall is suggested with adequate provision of 
tying, feeding, watering and milking inside of the barn. Open paddock area with continuous manger in one side along with covered standing space is provided attached to the barn for housing during warm/comfortable weather. In addition, the following important aspects also need adequate attention while deciding about the housing structure for dairy animals.

Cattle Shed in loose housing: The entire shed should be surrounded by a boundary wall of 4-5 $\mathrm{ft}$ height from three side and manger etc, on one side. Near the manger, under the roofed house 5 ' wide floor should be paved with bricks having a little slope. Beyond that, there should be open unpaved area. During cold wind in winter the animals will automatically lie down to have the protection from the walls. All along the manger, there shall be water trough to provide clean drinking water. The water trough thus constructed will also minimize the loss of fodders during feeding.

\section{Conventional Dairy house:}

The conventional dairy barns are comparatively costly and are now becoming less popular day by day. However, by this system cattle are more protected from adverse climatic condition. The following barns are generally needed for proper housing of different classes.

- Dairy cow sheds

- Calving box

- Isolation box

- Sheds for young stocks

- Bull or bullock sheds

Dairy cow sheds: Cow sheds can be arranged in a single row if the numbers of cows are small ie less than 10 or in a double row if the herd is a large one. Ordinarily, not more than 80 to 100 cows should be placed in one building. In double row housing, it should be so arranged that the cows face out (tails to tail system) or face in (head to head system) as preferred (Rajkumar C $P$, 2013).

\section{Advantages of tail to tail system (face out):}

- In cleaning and milking the cows, the wide middle alley is of great advantage.

- Lesser danger of spread of diseases from animal to animal.

- Cows can always get more fresh air from outside.

- The supervisor can inspect a greater number of milkmen while milking. This is possible

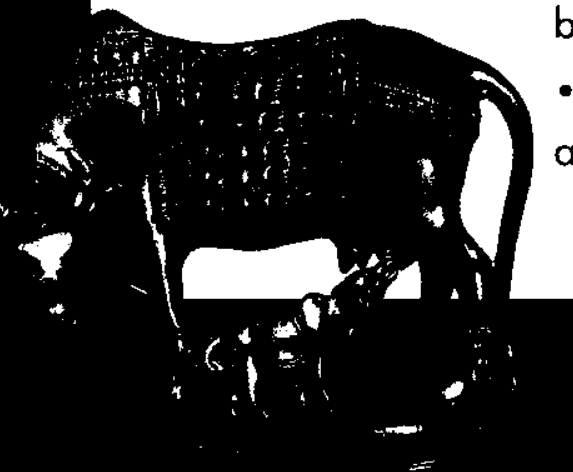
because milkmen will be milking on both sides of the supervisor. 


\section{Advantages of face to face system (face in):}

- Cows make a better showing for visitors when heads are together

- The cows feel easier to get into their stalls.

- Sun rays shine in the gutter where they are needed most.

- Feeding of cows is easier; both rows can be fed without back tracking.

- It is better for narrow barns.

Calving Boxes: Allowing cows to calve in the milking cowshed is highly undesirable and objectionable. It leads to sanitary problem in milk production and spread of disease in the herd. Special accommodation in the form of loose-boxes enclosed from all sides with a door should be furnished to all parturient cows. With ample soft bedding, it should be provided with sufficient ventilation through windows and ridge vent.

Isolation Boxes: Animals suffering from infectious disease must be segregated soon from the rest of the herd. Loose boxes of about 150 sq.ft are very suitable for this purpose. They should be situated at some distance from the other barns. Every isolation box should be self contained and should have separate connection to the drainage disposal system.

Sheds for Young Stocks: Calves should never be accommodated with adults in the cow shed. The calf house must have provision for daylight, ventilation and proper drainage. Damp and illdrained floors cause respiratory trouble in calves to which they are susceptible. For an efficient management and housing, the young stock should be divided into three groups, viz: young calves aged tip to one year, bull calves, female calves. Each group should be sheltered in a separate calf house/shelter. As far as possible the shed for young calves should be quite close to cow shed. Each calf shed should have an open paddock or exercise yard. It is useful to classify the calves below one year into three age groups, viz., and calves below the age of 3 months, 3-6 months old calves and those over 6 months for a better allocation of the resting area.

Bull / Bullock Shed: Safety and ease in handling a comfortable shed protection from weather and a provision for exercise are the key points while planning accommodation for bulls or bullocks. A bull should never be kept in confinement particularly on hard floors. Such a confinement without adequate exercise leads to overgrowth of the hoofs creating difficulty in mounting and loss in the breeding power of the bull.

Floor: The inside floor of the barn should be of some impervious material which can be easily kept clean dry and is not slippery. Paving with bricks can also serve ones purpose. Grooved cement concrete floor is still better.

Walls: The inside of the walls should have a smooth hard finish of cement, which will 
not allow any lodgment of dust and moisture. The wall should be about 4 to 5 feet in height and roofs supported by masonry work or iron pillars will be best or more suitable. The open space in between supporting pillars will serve for light and air circulation.

Roof: Roof of the barn may be of asbestos sheet or tiles. Corrugated iron sheets have the disadvantage of making extreme fluctuations in the inside temperature of the barn in different seasons. However, iron sheets with aluminum painted tops to reflect sunrays and bottoms provided with wooden insulated ceilings can also achieve the objective. A height of 8 feet at the sides and 15 feet at the ridge will be sufficient to give the necessary air space to the cows. An adult cow requires at least about 800 cubic feet of air space under tropical conditions. To make ventilation more effective continuous ridge ventilation is considered most desirable.

Manger: Cemented concrete continuous manger with removable partitions is the best from the point of view of durability and cleanliness. Low front mangers are more comfortable for cattle but high front mangers prevent feed wastage. The height at the back of the manger should be kept at about $3 \mathrm{ft}$. An overall width of about 2-2.5 ft is sufficient for a good manger.

Alleys: The central walk should have a width of about 5-6 ft exclusive of gutters when cows face out, and about 4-5 $\mathrm{ft}$ when they face in. The feed alley, in case of a face out system should be about $4 \mathrm{ft}$ wide, and the central walk should show a slope of 1 "from the center towards the two gutters running parallel to each other, thus forming a crown at the center.

Manure gutter: The manure gutter should be wide enough to hold all dung without getting blocked and be easy to clean. Suitable dimensions are 2" width. The gutter should have a gradient of 1 "for every $10 \mathrm{ft}$ length. This will permit a free flow of liquid excreta.

Doors: The doors of a single range cowshed should be about $5 \mathrm{ft}$ wide with a height of $7 \mathrm{ft}$ and for double row shed the width should not be less than 8-9 ft. All doors of the barn should lie flat against the external wall when fully open.

Slope/gradient: Proper and sufficient slope in the paddock is very important for maintaining clean and dry sheds. The slope in the open paddock should be 1: 60 for effective drainage of rain water. The slope of the standing space shall be 1:40. The slope in the drain should be 1 in 40. There should be shallow drain in open paddock for complete drainage of rain water.

Boundary wall/fence and gates: The boundary wall/ fencing material should be cheap and locally available. The effective height of the outer boundary wall for calf

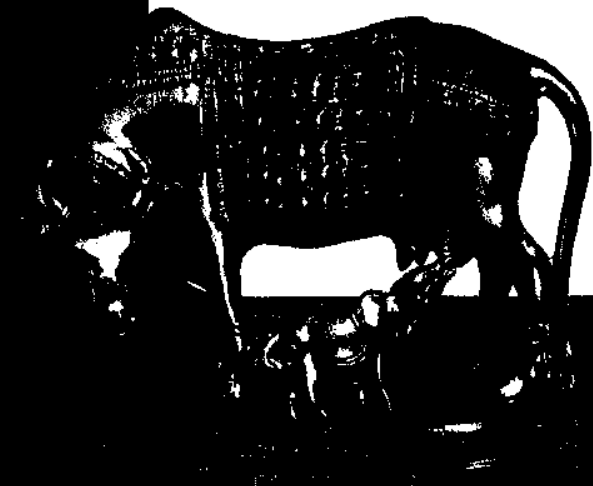
and adult may be 1.2 meter and 1.5 meters respectively. The boundary may be made by brick wall or iron railing. The provision of suitable size gates is also to be made in the boundary wall. 
Orientation of shelter: Shelter provides protection to the animals from various climatic extremes i.e., rainfall, hot and cold weather, wind, snow, frost etc. The orientation of shelter is to be such, so that it can give maximum protection to the animals. In coastal area, the sheds shall be oriented across the prevailing wind direction in order to protect the roof from being blown off by high wind at the same time to provide sufficient air movement in the shed. In humid region, building should be so sited as to avail the natural aeration and sunlight. The structure shall be east to west in coastal area and north to south in the hot dry area.

\section{Milking Systems:}

It is necessary to keep in view the milking practice in vogue, before the decision on designing and lay out of the milking parlours. In developed countries, where labour is scarce and expensive, machine milking has become very widespread and it is also practiced on many large commercial dairy farms in the tropics. Milking machines not only reduces labour requirement and eliminates the drudgery of hand milking, but in most cases performs a better quality milking operation than would be done by hand. However, most of the many small dairy farms in developing countries have a surplus of cheap labour and the number of cows milked at each of them is not sufficient to economically justify the installation of a machine. Furthermore, machines require power and are more expensive to purchase than the few pieces of equipment needed for hand milking. On commercial farms where several cows are milked at the time, a milking parlour becomes a feasible investment. Several types of milking parlours are in use in for dairy cattle.

Abreast parlour: The abreast parlour allows cows to enter and leave individually. The stands should be 1.0 to $1.1 \mathrm{~m}$ wide when a bucket milking machine is used or when hand milking is practiced, while 0.7 to $0.8 \mathrm{~m}$ is adequate when a pipeline milking system is installèd. In both cases the width for the milker should be 0.6 to $0.8 \mathrm{~m}$. The main drawback with the abreast parlour is the relatively long distance to walk between milking points and cows obstructing the milker since they share the same floor space.

Tandem parlour: The tandem parlour also allows for individual care of the cows. It is used mostly for smalier commercial herds and in particular for herds with high yielding cows. The parlour capacity in terms of cows milked per hour and labour efficiency can compare to that of a small herringbone parlour. The main drawbacks with this type of parlour are its larger space requirement and more expensive construction when compared to other types of parlour of similar capacity

Walk-through parlour: In walk-through or chute parlours cows enter and leave in batches. They have been used mainly for small herds. Their narrow width can be an advantage where a parlour is to be fitted in an existing building, but it is inferior to other types in most other respects, however, it is cheaper to construct than a tandem parlour. 
Herringbone parlour: The herringbone parlour layout results in a compact working area and allows feeders to be fixed to the side walls. Four stands on each side of the pit, is the minimum size of this type for high labour efficiency. The popularity of the herringbone parlour is mainly due to its simplicity and its high capacity measured in numbers of cows milked per man-hour. However, the risk of cows kicking the milker is greater in this type than in parlours where the milker stands alongside the cow.

Collecting yard: The cows are normally assembled in a collecting yard (holding area) before milking. This may be a portion of the yard that is temporarily fenced off with chains. The collecting yard should have a minimum size of 1.1 to $2.0 \mathrm{~m}^{2}$ per cow. The collecting yard should be paved for easy cleaning and to allow for sanitary conditions in the parlour. A roof is desirable for shade and to avoid wet cows entering the parlour in the rainy season.

\section{Space Requirements of Dairy Animals:}

The BIS recommendations generally agree with the figures suggested by several other workers for cattle in wormer regions. Cattle and buffaloes in worm regions mostly lie down during night time (Gerewal et al, 1982 and Barua et al, 1982). Hence the need to provide adequately large open or paddock area per animal in loose houses, as it is in the open area rather than under the shelter. For this very reason feed manger must be provided in the paddock area also so that animals can feed at night. The space requirements of dairy animal's floor, feeding manger, watering trough as per Bureau of Indian Standards (BIS) are given in table below (B.I.S, 2011).

\begin{tabular}{|c|c|c|c|c|c|c|}
\hline $\mathbf{S I}$ & Animal type & $\begin{array}{l}\text { Floo } \\
\left(\mathrm{M}^{2}\right) \\
\text { Cov- } \\
\text { ered } \\
\text { area }\end{array}$ & $\begin{array}{l}\text { space } \\
\text { animal } \\
\text { Open } \\
\text { area }\end{array}$ & $\begin{array}{c}\text { Manger } \\
\text { space } \\
(\mathrm{cm}) / \\
\text { animal }\end{array}$ & $\begin{array}{c}\text { Water } \\
\text { trough } \\
\text { space }(c m) / \\
\text { animal }\end{array}$ & $\begin{array}{l}\text { Mode of hous- } \\
\text { ing }\end{array}$ \\
\hline 1 & Young calves $(<8$ weeks) & 1.0 & 2.0 & $40-50$ & $10-15$ & $\begin{array}{l}\text { Individual or in } \\
\text { groups of }<5\end{array}$ \\
\hline 2 & Older calves (> $8 \mathrm{wks}$ ) & 2.0 & 4.0 & $40-50$ & $10-15$ & Groups of $<15$ \\
\hline 3 & Heifers & 2.0 & $4.0-5.0$ & $45-60$ & $30-45$ & Groups of $<25$ \\
\hline 4 & Adult cows & 3.5 & 7.0 & $60-75$ & $45-60$ & Groups of $<25$ \\
\hline 5 & Adult Buffaloes & 4.0 & 8.0 & $60-75$ & $60-75$ & Groups of $<25-30$ \\
\hline 6 & Down calvers & 12.0 & $20-25$ & $60-75$ & $60-75$ & Individual \\
\hline 7 & Bulls & 12.0 & 120.0 & $60-75$ & $60-75$ & Individual \\
\hline
\end{tabular}




\begin{tabular}{|c|c|c|c|c|c|c|}
\hline \multirow[b]{2}{*}{ SI } & \multirow[b]{2}{*}{ Animal type } & \multicolumn{2}{|c|}{$\begin{array}{l}\text { Floor space } \\
\left(\mathrm{M}^{2}\right) / \text { animal }\end{array}$} & \multirow{2}{*}{$\begin{array}{l}\text { Manger } \\
\text { space } \\
(\mathrm{cm}) / \\
\text { animal }\end{array}$} & \multirow{2}{*}{$\begin{array}{c}\text { Water } \\
\text { trough } \\
\text { space }(\mathrm{cm}) / \\
\text { animal }\end{array}$} & \multirow{2}{*}{$\begin{array}{l}\text { Mode of hous } \\
\text { ing }\end{array}$} \\
\hline & & $\begin{array}{l}\text { Cov- } \\
\text { ered } \\
\text { area }\end{array}$ & $\begin{array}{l}\text { Open } \\
\text { area }\end{array}$ & & & \\
\hline 8 & Bullocks & 3.5 & 7.0 & $60-75$ & $60-75$ & Pairs \\
\hline
\end{tabular}

* The actual length and width of water through may be decided as per the strength of group and size of the paddock.

\section{Sketch of dairy farm for $\mathbf{2 0 0}$ animals:}

For dairy animals loose housing system has been recommended for most of the agro-climatic zones of India with minor modifications except in heavy rainfall regions and in the high altitude regions where winters are very harsh. Sketch layouts for the construction of different farm buildings have been given for loose housing system as follows (Kamboi, 2012).

LAYOUT OF BETIDINGS YOR $20 \%$ COWS B.ASED DAIRY PARM

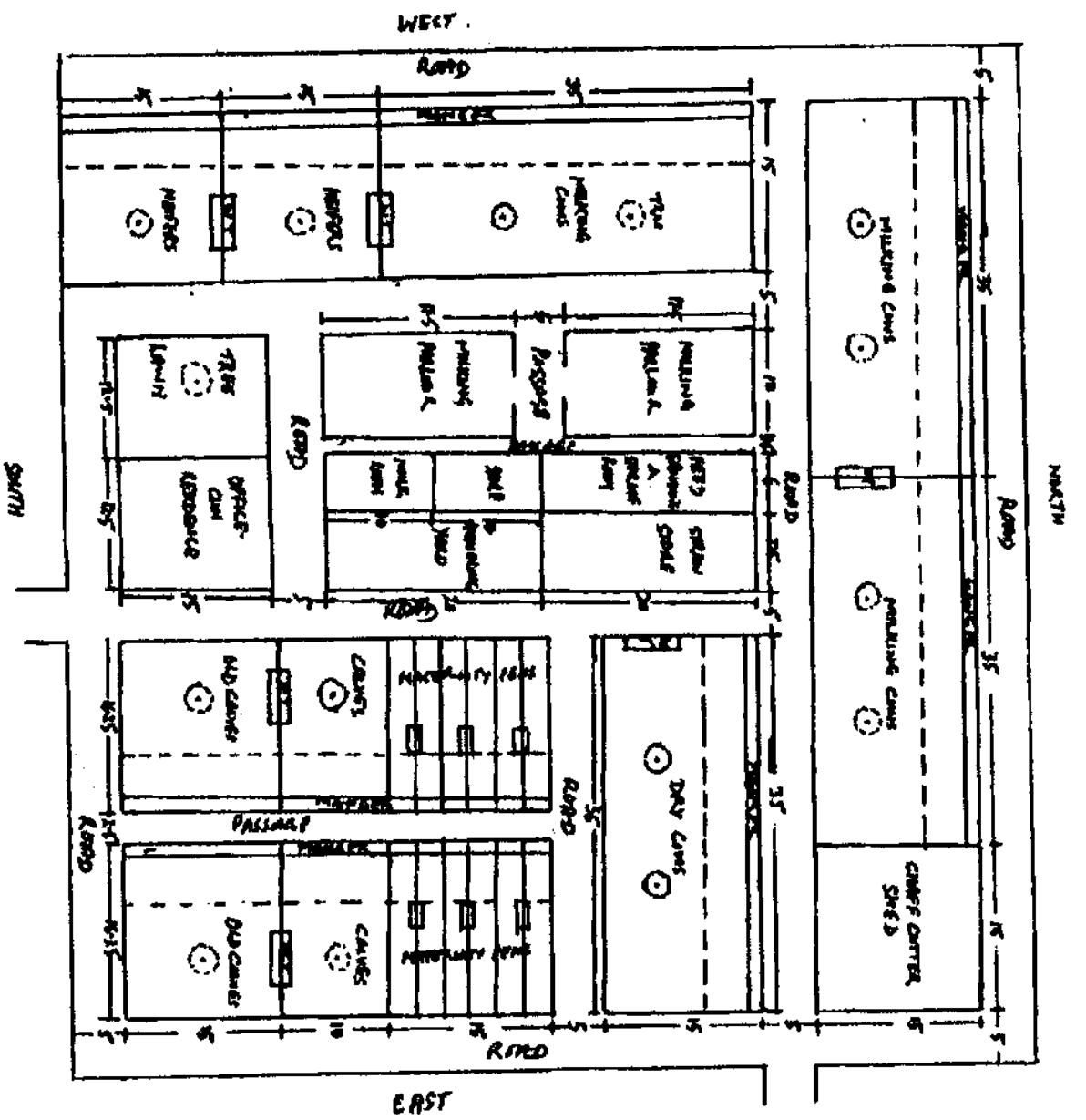

* All dimensions are in metror. WT- unter tringl. 
MILK, a naturally unique food loaded with indispensible essential micronutrients needed to keep the body strong and healthy. World Milk Day is a day we re-affirm all the goodness that milk represents; its natural origin and great nutritional value that so many people all over the world enjoy.

Everyone should drink and celebrate the goodness of milk because it is rich in essential micronutrients for all age groups. It provides building blocks for a healthy life. Children are energetic, and need daily nutrients; Adults need vital nutrients such as proteins, vitamins and minerals for the daily maintenance of their body. Elderly people need more calcium, protein and vitamin B12 as they get older. Milk indeed provides all and more of these nutrients. Hence, we should "Drink Milk Every Day".

\section{References:}

B.I.S (2011). Bureau of Indian Standards for space requirements of dairy animal's floor, feeding manger watering trough.

New Delhi IS - 5605 ( Part II).

Barua KC, Pal R N and Sastry N S R (1982). Housing management for dairy cattle. Haryana agriculture University Journal of Research 11: 58-59.

Champak Bhakat and Sahani M S (2006). Management and potentiality of dairy cattle in hot arid Thar desert. Chapter in Book Arid Ecology, Published by Madhu Publication, Bikaner, Rajasthan.

Grewal S S, Sastry N S R and Yadav R S (1982). System of housing for cow and buffalo. India Journal of Animal Science. $52: 58$ - 60 .

Kamboj ML (2012). Model layouts of dairy farms of various sizes. Web page free access of layoutofdairyfarm.co.in; 1.4 .

Rajkumar C P (2013). Housing site for dairy cattle, AC\&Rl, Web page of http://bieap.gov.in/ DairyAnimalManagementTheory.pdf, 1-3.

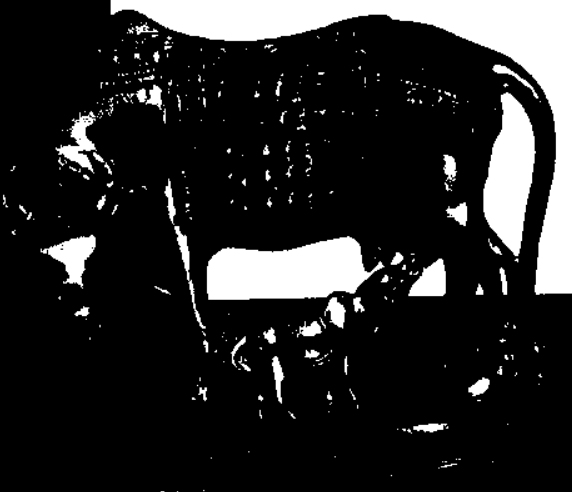

